\title{
Identidade e comunhão entre gentios e judeus, na igreja
}

\section{Identity and communion between Gentiles and Jews, in the church}

\section{Identidad y comunión entre gentiles y judíos, en la iglesia}

\author{
Prof. Me.Silvio Cezar José \\ Pereira Gomes
}

Submissão: 04-02-2021

Aceite: $15-04-2021$

\author{
* Universidade Metodista de São Paulo \\ Doutorando em Ciências da Religião (UMESP), \\ silviorazec@gmail.com
}

\begin{abstract}
RESUMO
A partir da nova perspectiva de Paulo, este trabalho tem como objetivo refletir sobre a posição que os gentios tinham dentro da comunidade dos seguidores de Jesus de Nazaré, após o evento pascal. Por meio de análises do relato da ida de Paulo à Jerusalém e da versão paulina do incidente em Antioquia, registrados em Gálatas, do texto do concílio em Jerusalém, em Atos e da tradição oral rabínica sobre os gentios convertidos ao judaísmo, se tentará conhecer os gentios da comunidade. Quem são os gentios seguidores de Jesus? Como eles eram vistos entre os judeus seguidores de Jesus? São gentios convertidos ao judaísmo? E como ficam as questões a respeito da impureza dos gentios? Ainda que com pouco espaço, este trabalho visa lançar luzes sobre essas questões.

Palavras-chave: Gentios; judeus; Paulo; Tiago; rabinos.
\end{abstract}

\begin{abstract}
Under the new perspective of Paul, this work will to reflect on the position that the Gentiles had in the community of the followers of Jesus of Nazareth, after the Easter event. It will analize the account of Paul's visit to Jerusalem and the Pauline version about the incident in Antioch, both recorded in Galatians, the text of the council in Jerusalem and the oral rabbinic tradition about the Gentiles converted to Judaism, to try to know the gentiles from the community. Who are the Gentile followers of Jesus? How were they seen among the Jewish followers of Jesus? Are Gentiles converted to Judaism? And what about the questions about the uncleanness of them? These are the questions of this work.
\end{abstract}

Keywords: Gentiles; Jews; Paul; James; rabbis.

\section{RESUMEN}

Desde la nueva perspectiva de Pablo, este trabajo pretende reflexionar sobre la posición que tenían los gentiles, dentro de la comunidad de seguidores de Jesús de Nazaret. A través del análisis del relato de la visita de Pablo a Jerusalén y la versión paulina del incidente de Antioquía, registrado en Gálatas, el texto del concilio de Jerusalén y la tradición rabínica oral sobre los gentiles convertidos al judaísmo, se intentará conocer el Gentiles de la comunidad. ¿Quiénes son los seguidores gentiles de Jesús? ¿Cómo fueron vistos entre los seguidores judíos de Jesús? ¿Los gentiles se convierten al judaísmo? ¿Y las preguntas sobre la inmundicia de los gentiles? Aunque con poco espacio, esta visión del trabajo arroja luz sobre estos temas. Palabras clave: Gentiles; judíos; Pablo; Santiago; rabinos. 


\section{Introdução}

Nas tradições sinóticas mais antigas, já existia a ideia de que Cristo compreendia, ou passou a compreender, que sua obra incluiria os gentios (Mc 7.24-29). Porém, tal compreensão não é atestada tão tarde. Paulo é testemunha de uma abertura aos gentios que fez com que ele passasse a ser visto como "O apóstolo dos gentios". Ele mesmo diz que lhe foi confiado o "evangelho da incircuncisão" (Gl 2.7). No livro de Atos, essa abertura se torna uma prática da comunidade a partir da experiência de Pedro, que foi chamado para comparecer à casa do centurião Cornélio e descobriu que Deus derramaria, sobre os gentios, o mesmo Espírito que havia derramado sobre os judeus seguidores de Jesus, no dia de Pentecostes (At 10.22).

O que ainda parece não estar claro é a identidade desses gentios, na comunidade fundada pelos seguidores do mestre de Nazaré. Já é mais do que seguro afirmar que Jesus não foi o fundador do cristianismo e que, também, mesmo Paulo, depois de passar anos sob esse título, hoje já não o detém. O mais comum, na pesquisa bíblica, hoje em dia, é encontrar estudos que reforcem o caráter judaico do movimento de Jesus e mesmo do apóstolo Paulo - com algumas ressalvas que não cabem nesse trabalho e que, como o próprio Carlos Gio Arbiol diz, é um debate sem fim (ARBIOL, 2018, p. 105).

Portanto, não há dificuldade em afirmar que os judeus seguidores de Jesus são pessoas que etnicamente pertencem ao povo judeu e são, também, fiéis à fé e à tradição judaicas. E quanto aos seguidores gentios? São classificados simplesmente como "gentios", iguais aos que também o são, mas não seguem ao Mestre judeu? O movimento de Jesus foi uma reforma judaica que passou a aceitar a conversão ao judaísmo sem a prática da circuncisão? São a essas perguntas que esse trabalho busca responder.

Para tanto, serão realizadas análises das tradições presentes no concílio de Jerusalém, que emitiu diretrizes aos gentios convertidos; na carta aos Gálatas, por conta das dicas que ela possui a respeito desse assunto; e nos escritos rabínicos, onde temas desse tipo também foram alvo de debate. Dessa forma, se quer mostrar que a comunidade nascente não inovou em sua teologia, antes, manteve-se fiel a diretrizes da sua tradição oral.

De início, a primeira abordagem tentará entender como o judaísmo, em sua pluralidade, tratava os gentios que se aproximavam do judaísmo. Depois, se observará essa mesma aproximação entre os judeus que seguiam o Mestre de Nazaré. Houve mudanças? Se sim, quais?

A crise em Antioquia e a carta aos Gálatas ajudarão na análise final, após recolher as informações anteriores a respeito da prática do judaísmo com os 
gentios convertidos. Por fim, uma proposta de interpretação que parte das interpretações possíveis encontradas na pesquisa bíblica.

\section{Paulo, os gentios e a nova perspectiva}

Em uma visão antiga sobre o apóstolo Paulo, se compreendia o apóstolo como um evangelizador de uma nova religião, o cristianismo (ARBIOL, 2018, p. 114). Naquele tempo, havia, inclusive, quem dissesse que Paulo era o inventor do cristianismo. Entrou para a história até mesmo uma denominação preconceituosa sobre seus adversários: judaizantes. Sendo assim, Paulo seria um "desjudaizante". Sua visão sobre a Lei era considerada negativa e revogadora. Sobre o incidente em Antioquia, Jeremy Murphy-O’Connor diz:

A conclusão que Paulo tirou desse incidente foi a de que a sua tolerância tinha sido um erro. Por conseguinte, tornou-se radicalmente antimonista. A sua nova postura foi exposta com grande precisão por Tiago, a fim de alertar Paulo para o perigo que corria devido aos zelotes jerosolimitanos: "Foram avisados acerca de ti, que ensinas todos os judeus a viver no meio de gentios e a esquecer Moisés, dizendo-lhes para não circuncidar os filhos nem para observar os costumes" (At 21.21). (...) Antioquia forçou-o a perceber que dar espaço à lei em qualquer comunidade cristã, por menor que fosse, era criar um inimigo para Cristo. (MURPHY-O'CONNOR, 2008, p. 103-105).

Essa visão de Murphy-O'Connor ainda está ligada a essa antiga perspectiva, que via Paulo como contrário à lei. Nesse ponto de vista, não há nem o que discutir a respeito da identidade dos gentios. Judeus e gentios, seguidores de Jesus, são cristãos. A própria expressão "comunidade cristã" denota a compreensão de que se tem em vista outra religião. Quer etnicamente judeus, quer gregos, na comunidade, são todos cristãos e, para Paulo, mesmo os judeus devem "esquecer Moisés". Sendo assim, os gentios eram vistos como alvos de Paulo para a conversão a uma religião nova, derivada, porém diferenciada do judaísmo. E Pedro, o apóstolo da circuncisão, teria a responsabilidade de levar judeus a essa compreensão.

Nessa nova religião, não há lugar para exigir cumprimento da Lei de Moisés e/ou circuncisão. Daí que as defesas paulinas contra os judaizantes são vistas como defesa de uma doutrina nova, de uma revelação, ou religião ainda não compreendida.

A partir de E. P. Sanders e sua obra, Paul and palestinian Judaism, passou-se a se considerar uma nova perspectiva sobre Paulo. Ainda que, como Murphy-O'Connor, existam os que ainda alimentam a antiga perspectiva. $\mathrm{Na}$ visão atual, Paulo tem sido compreendido como um judeu fiel à sua tradição 
como judeu. Obviamente, nisto também se inclui a lei: "viver no Espírito e viver de acordo com a lei não devem ser considerados como opostos na mente de Paulo. A vida no Espírito tem como resultado a obediência à lei" (SANDERS, 2009, p. 133).

Dentro dessa perspectiva, onde Paulo é visto como judeu, seguidor das tradições e da ética judaica, também a visão sobre os gentios das igrejas paulinas passam por ter necessidade de certa "revisão". Afinal, já não se trata de nova religião. É a mesma religião (judaísmo) e mesma separação étnica: judeus de um lado, gentios de outro. Paulo convertia gentios ao judaísmo? As comunidades judaicas, que eram seguidoras do Mestre Jesus, aceitavam gentios como judeus ou como gentios? Qual era sua identidade?

É dentro dessa visão já consolidada sobre Paulo que este artigo fará uma breve investigação a respeito de quem são e como eram vistos os convertidos gentios à essa nova facção judaica, surgida em torno do Mestre de Nazaré.

\section{Os gentios convertidos ao judaísmo}

Em uma tentativa de tentar identificar esse grupo de gentios que fazem parte da comunidade dos seguidores do Mestre de Nazaré, John Dominic Crossan encontra os termos "tementes a Deus", ou "adoradores de Deus". De fato, como ele mesmo menciona em sua obra Em busca de Paulo, esse termo aparece em Afrodisia, em uma coluna de mármore que, provavelmente, pertencia à sinagoga da cidade:

A face $a$ enumera 19 nomes de membros do "decanato", ou liderança do projeto. Desses, 14 nomes são nomes judaicos, 3 de prosélitos, 2 dos que se chamavam "adoradores de Deus" (theosebeis). Estes últimos 5 estão intercalados entre os primeiros 14, estando junto com eles os adoradores de Deus. Os prosélitos estão em outro lugar. A face $b$ exibe uma lista de 55 nomes separados espacialmente e com clareza de uma lista de 52 nomes embaixo. Os primeiros com a frase: "e tais são os adoradores de Deus" (kaî hosoi theosebeis), Essa é a mais longa inscrição judaica da antiguidade e indica a existência de estreita cooperação entre judeus (prosélitos inclusive) e pagãos simpatizantes. Aqui, com mais clareza e certeza do que em qualquer outro lugar, aparecem esses enigmáticos "adoradores de Deus" do livro de Atos de Lucas, gravados em pedra. (CROSSAN; REED, 2007, p. 32) - itálicos do autor.

O termo theosebeis, porém, não aparece no livro de Atos. Antes, Crossan

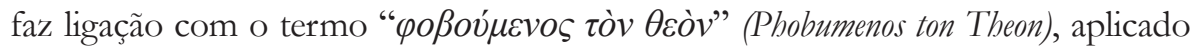
a Cornélio, em Atos, e à informação sobre o centurião, em Lucas, que ajudou a construir a sinagoga (Lc 7.4-5). Para Crossan, os "adoradores de Deus", listados na coluna de mármore, estão na mesma classificação que o Cornélio 
"temente a Deus" e o centurião que "ama nossa nação" (a judaica), a quem ele chama de "simpatizantes". O termo parece genérico demais, os judeus já tinham uma nomenclatura para esses gentios que se aproximavam do judaísmo.

Este grupo, em particular, aparece nos escritos rabínicos como "convertidos residentes". Não são os chamados "prosélitos de justiça", ou "prosélitos integrais" (JEREMIAS, 2017, p. 424). Cabe, aqui fazer diferenciação entre esses dois grupos. Segundo Joachim Jeremias, os convertidos residentes eram gentios que "aceitavam somente a profissão de fé monoteísta e a observância de uma parte das leis cerimoniais, sem se converterem totalmente ao judaísmo. Legalmente, eram considerados pagãos" (JEREMIAS, 2017, p. 424). Ou seja, tratam-se de gentios de fato. Não são considerados judeus, porém, professavam a fé no Deus dos judeus e observavam algumas leis e mandamentos. Podendo, inclusive, como a história demonstra e os textos bíblicos confirmam, gozar de simpatia do povo judeu - como o caso do Centurião na versão de Lucas 7.3-5:

E, quando ouviu falar de Jesus, enviou-lhe uns anciãos dos judeus, rogando-lhe que viesse curar o seu servo. E, chegando eles junto de Jesus, rogaram-lhe muito, dizendo: É digno de que lhe concedas isto, Porque ama a nossa nação, e ele mesmo nos edificou a sinagoga.

Já os "prosélitos integrais", ou "prosélitos de justiça”, eram "pagãos convertidos ao judaísmo, submetendo-se à circuncisão, ao banho ritual e à oferta de sacrifício" (JEREMIAS, 2017, p. 424). O "banho ritual" poderia, facilmente, ser confundido com o batismo frequentemente citado no Segundo Testamento, porém, a ausência da circuncisão, tema bastante defendido por Paulo, demonstra que se trata de outro rito, ou outras condições para ingresso em uma comunidade. No caso da comunidade dos seguidores do Mestre Jesus, os seus gentios convertidos não eram judeus. Estavam, na verdade, no primeiro grupo. No grupo dos convertidos residentes que ainda eram considerados gentios.

Crossan entende que a missão de Paulo era converter esses gentios "convertidos residentes" ao cristianismo. E aqui mora, possivelmente, um equívoco de cálculo de Crossan. Ele entende que Paulo está pregando uma outra religião, diferente da judaica, e busca converter os gentios simpatizantes a esse novo grupo religioso. A ideia de apresentar Paulo como pregador de uma nova religião foge ao entendimento da nova perspectiva sobre Paulo (ARBIOL, 2018, p. 114-115) e, ao mesmo tempo, por isso, acaba não encontrando quem, de fato, são e qual o lugar desses tais "simpatizantes", que é a expressão usada por Crossan. 
A existência histórica desses simpatizantes, ou "estrangeiros residentes" é atestada, por exemplo, na coluna que Crossan se reporta. Resta, agora, entender o que os judeus esperavam desses "estrangeiros residentes". Se não eram considerados judeus legítimos, se não eram nem "convertidos de justiça”, então, quais eram os mandamentos que eles deveriam seguir? Qual era sua parte, dentro da tradição judaica? Segundo os escritos rabínicos em Sanhedrin 56a:

Desde que o halakhot dos descendentes de Noé foi mencionado, uma discussão completa sobre o mitžvot de Noé é apresentada. Os Sábios ensinados em uma baraita dizem: Os descendentes de Noé, ou seja, toda a humanidade, foram ordenados a observar sete miţ̧vot: A miţ̧va de estabelecer tribunais de julgamento; e a proibição de abençoar, ou seja, xingar, o nome de Deus; e a proibição da adoração a ídolos; e a proibição de relações sexuais proibidas; e a proibição de derramamento de sangue; e a proibição de roubo; e a proibição de comer um membro de um animal vivo (tradução própria).

Esses mandamentos são válidos para todos os gentios, chamados de “descendentes de Noé", porém, para os judeus, o total de mandamentos são 613 - a Torá "inteira". Logo, o que se cobrava desses simpatizantes, ou "convertidos residentes" é que cumprissem os sete mandamentos. Seria possível encontrar essas orientações espalhadas nas cartas de Paulo? O apóstolo via esse grupo como "convertidos residentes", ou como prosélitos? A rejeição, por parte de Paulo, de que esses gentios sejam circuncidados, revela que, para o apóstolo, eles não eram e não deveriam se tornar judeus? Não sendo judeus, com que autoridade Paulo poderia tornar-se mestre deles, se não fosse pela crença de que, dentro da tradição judaica, existe um espaço para que tal ocorra?

\section{Os gentios entre judeus-cristãos}

Pode-se investigar, nas cartas e nos textos de Atos, como, de fato, esse grupo era encarado e como havia duas tendências, dentro da comunidade, sobre como os judeus seguidores de Jesus deveriam se comportar, diante dos irmãos gentios. Por ora, serão verificados os sinais que demonstram que esse grupo não era de prosélitos de justiça, ou seja, judeus convertidos.

Tito é o primeiro sinal que podemos analisar. Como parte de grupo de gentios seguidores de Jesus de Nazaré, não precisou ser circuncidado, quando foi à Jerusalém, com Paulo, encontrar os outros apóstolos (Gl 2.3). Se ele não era circuncidado, então não havia se tornado um judeu, mesmo sendo membro da igreja. Embora Paulo trate isso como argumento contra seus adversários, como visto anteriormente, trata-se de algo comum, dentro do judaísmo. 
O relato de Paulo acaba demonstrando que a presença de gentios seguindo o Mestre Jesus não era malquista. Se Crossan estiver certo, Tito seria um convertido residente que passou a seguir a vertente judaica de Jesus, o Nazareno. Caso não esteja certa, e Paulo tenha evangelizado um gentio que sequer cria no Deus dos judeus, ainda assim, a partir daquele momento, Tito era visto como um convertido residente. No primeiro caso, nem mesmo mudou de religião, apenas seguiu para outra facção que não exigia a conversão para que se tornasse membro. No segundo, converteu-se parcialmente ao judaísmo, sem realizar qualquer conversão completa à religião. Ou seja, em ambos os casos, continuava sendo gentio.

Em Atos, Pedro se torna o pioneiro na missão aos gentios e o segundo sinal a ser analisado neste trabalho. Sua ida à casa de Cornélio, no entanto, foi considerada como um erro, pois Pedro entrara na residência de gentios e comera com eles, o que o tornaria impuro (At 11). Os próprios "tementes a Deus" sabem disso (Lc 7.6). Pedro, todavia, usa o argumento da revelação dada a ele sobre o que é puro e o que é impuro. O argumento é bem-vindo na comunidade e passam a compreender sua missão aos gentios.

A questão da pureza, entretanto, é a razão de "os da parte de Tiago" não conseguirem encarar com bons olhos, o fato de Paulo, Pedro, Barnabé e outros judeus que estavam com estes, se sentarem à mesa com seguidores gentios de Jesus, em Antioquia (Gl 2). E este é o terceiro sinal a ser analisado. Apesar de professarem a mesma fé e seguirem ao mesmo Mestre, a cultura e a identidade étnica estavam preservadas: judeus eram judeus, gentios eram gentios. E como os judeus seguem a lei de Moisés - não seguida e nem exigida dos gentios eles não podem se sentar à mesa com pagãos. Mesmo sendo "seus pagãos".

Este episódio, inclusive, revela que a comunidade estava dividida sobre a comunhão na mesa, entre judeus e gentios. Tema que o argumento "Tito", utilizado por Paulo, não trata. Indiretamente, porém sem deliberar como regra da comunidade, esse tema está sendo tratado no episódio de Pedro. Seria essa a tradição que fundamenta o porquê de, nesse assunto, Pedro discordar de Tiago e do seu grupo - apesar de não se sentir à vontade para encará-los? $\mathrm{Na}$ tradição sinótica, essa divisão de opiniões também pode ser percebida e, ao mesmo tempo, demonstra ser o quarto sinal que podemos avaliar de qual seria a identidade dos gentios na igreja.

Jesus, em Lucas, por exemplo, estava se dirigindo à casa do centurião romano - os romanos, inclusive, eram os responsáveis pela constante desconfiança que os judeus tinham dos gentios, "entre eles Rabino Eliezer, pensavam que os gentios pagãos, particularmente os romanos, estavam colocando o Judaísmo em perigo" (GUTTMANN, 1957, p. 124). Logo, o Cristo lucano 
entraria na casa de gentios romanos e Lucas não coloca reação negativa dos judeus que estão ao lado de Jesus - que, aliás, foram interceder pelo centurião.

A versão de Lucas poderia ser justificada pelo fato de ser companheiro de Paulo, segundo a tradição, e seu evangelho possui afinidades com a chamada teologia paulina, bem como sua comunidade ter ideais paulinos (MONASTERIO; CARMONA, 2012, p. 115), além, obviamente, de ele mesmo ser um gentio. Também estaria em acordo com o Pedro de Atos, portanto, há uma ideologia em debate que transformou Jesus em um tolerante que, na verdade, poderia não ser.

Contudo, considerando a validade dessa explicação, ao mesmo tempo, limita-se a doutrina da aceitação dos judeus em casa, ou em mesa, com os gentios, como algo paulino ou invenção paulina. Quando, na verdade, trata-se de uma compreensão judaica, da qual Paulo compartilhava com Pedro, Barnabé e outros judeus não nomeados. Isto, Lucas também deixa claro, ao demonstrar que os judeus iriam, com Jesus, à casa do centurião. Ademais, a comunidade mateana tem a mesma interpretação. O que afastaria a exclusividade das igrejas paulinas.

$\mathrm{Na}$ versão de Mateus, há outro detalhe: o centurião tem acesso direto a Jesus, para fažer o pedido. Não precisa de intercessão de anciãos judeus (Mt 8.5). O que demonstra que essa comunidade também acreditava na inclusão dos gentios (os convertidos residentes) à comunhão dos judeus - mesmo o próprio gentio não entendendo a visão de Jesus e não lhe aceitando em sua casa. Os gentios da comunidade tinham uma mensagem clara: aceitaremos não frequentar suas casas, se isso os escandaliza, porém, o ideal do Mestre Jesus é ultrapassar essas barreiras.

Lembrando do que foi dito sobre Pedro, ainda analisando as narrativas antigas, que não podem ter garantias históricas, o Pedro de Lucas, em Atos, entra na casa de Cornélio. Da mesma forma, o Pedro histórico, no episódio narrado por Paulo, em sua carta aos Gálatas, participou da mesa com gentios, enquanto ainda estava ausente o grupo de Tiago. Isso demonstra alguma afinidade entre as ideias do Pedro histórico com o apresentado no livro de Atos dos apóstolos.

A história do centurião, porém, na tradição joanina, inverte a situação e pode dar indícios de que a comunidade está dividida a respeito desse assunto. $\mathrm{O}$ centurião vira um oficial do rei e o servo vira filho. Este oficial toma a iniciativa de falar com Jesus (assim como em Mateus), mas o pedido é que Jesus vá até sua casa. Ele quer que Jesus vá à sua casa. Diferente das outras versões, Jesus não parece interessado em ir e ainda dúvida da fé do oficial do rei/centurião. Com a insistência, Jesus opera o milagre de longe, por sua escolha em não ir 
com o homem em sua casa (João 4.46-54). Isso pode demonstrar que, mesmo depois de anos, a comunidade judaica, seguidora de Jesus, ainda debatia a respeito dessa questão. Vale a lembrança de que o texto afirma que, após isso, o oficial do rei se tornou crente, tanto ele quanto sua casa.

Talvez, pela versão até mais curta, a tradição Joanina preserve o relato mais antigo, onde mesmo Jesus fazia separação entre judeus e gentios? Esta análise, porém, ficará para outro trabalho.

Ainda sobre os sinais gentílicos desse grupo, Justin Taylor, ao analisar a carta do concílio dos apóstolos, registrada no livro de Atos, interpreta que a os gentios da igreja eram os convertidos residentes. Ele diz que os mandamentos listados na carta dos apóstolos são "protomandamentos dos Filhos de Noé” (TAYLOR, 2001, p. 377) - tradução própria. De fato, se a lista de Atos for observada com atenção, possui eco nos mandamentos obrigatórios desses convertidos "incompletos":

\begin{tabular}{|l|l|}
\hline Sanhedrin 56a & Atos $\mathbf{1 5 . 2 9}$ \\
\hline a proibição da adoração a ídolos & $\begin{array}{l}\text { Que vos abstenhais das coisas sacrifica- } \\
\text { das aos ídolos }\end{array}$ \\
\hline a proibição de relações sexuais proibidas & das uniões ilegítimas \\
\hline $\begin{array}{l}\text { a proibição de comer um membro de } \\
\text { um animal vivo }\end{array}$ & das carnes sufocadas e do sangue \\
\hline
\end{tabular}

Como Taylor diz, trata-se dos protomandamentos dos Filhos de Noé, contudo, ainda assim, é possível perceber o eco dos demais mandamentos nas cartas endereçadas a igrejas gentílicas. A exemplo, diz Sanhedrin que é necessário "estabelecer tribunais de julgamento", como um dos mandamentos para os Filhos de Noé. Na carta aos Coríntios, Paulo fica surpreso ao descobrir que os corintos colocam pessoas fora da comunidade para realizar o julgamento de demandas entre membros dela: "Para vos envergonhar o digo. Não há, pois, entre vós sábios, nem mesmo um, que possa julgar entre seus irmãos? Mas o irmão vai a juízo com o irmão, e isto perante infiéis" (1Co 6.5-6).

Uma ausência clara do funcionamento correto desse sistema que eles são obrigados, pela lei dos filhos de Noé, a estabelecer. Mesmo porque, a comunidade se submete à moral que resolveu seguir, acima da moral e lei estatais. Se faz necessário que essa comunidade saiba e tenha condições de resolver as demandas "judiciais" que podem surgir.

Ainda em Corinto, é possível notar a reafirmação desses protomandamentos, onde, inclusive, se inclui a proibição do roubo: "Mas agora vos escrevi que não vos associeis com aquele que, dizendo-se irmão, for devasso, 
ou avarento, ou idólatra, ou maldizente, ou beberrão, ou roubador; com o tal nem ainda comais" (1Co 5.11). Nas cartas pastorais, existem as personagens chamadas Himeneu e Alexandre, que foram entregues a Satanás, por conta de blasfêmia (1Tm 1.20). Por outro lado, não se poderá encontrar, por exemplo, uma exortação paulina para que guardem o sábado; circuncisem seus filhos, no oitavo dia; ou que tenham que ir ao templo, na páscoa. Paulo não cobra comportamento judeu das igrejas gentílicas. Contudo, sua cobrança encontra-se bem embasada na tradição oral daquilo que seria chamado de Mandamentos dos Filhos de Noé.

\section{O concílio de Jerusalém e a crise em Antioquia}

Como demonstrado no tópico anterior, a grande questão que estava presente na comunidade era se caberia a mesa dos gentios possuir a presença de um judeu, ou vice-versa. Também como já dito, Pedro, Paulo, Barnabé e alguns outros que Paulo chama de "outros judeus", parecem não concordar com a ideia de duas mesas separadas. Tiago, por outro lado, junto com um grupo que o segue, considera que a mesa tem que ser separada. Esse grupo parece ter maior influência, para que Pedro e Barnabé passassem a se afastar dos gentios, com a chegada dos "da parte de Tiago".

Não se sabe se o grupo comumente chamado de "judaizante" faz parte do grupo de Tiago. Ao que parece, são judeus que consideram imperativo que os "convertidos residentes" se tornem prosélitos de justiça. Em uma expressão um tanto quanto preconceituosa contra os fariseus, Lucas, em Atos, faz parecer que esse grupo seguia o farisaísmo, antes de seguir o Caminho (At 15.5).

Neste episódio, se nota que a preocupação é que sigam a Lei de Moisés, ou seja, até então, estão sob outra lei, no caso, os Mandamentos dos Filhos de Noé. Lucas dá a entender que o fato de serem fariseus fazia com que pensassem desse jeito, porém, dentro do grupo de fariseus, havia a escola de Shammai, completamente contrária à aceitação de gentios. Por outro lado, o grupo de Hillel considerava, inclusive, que era missão dos judeus libertar os gentios da idolatria e torná-los convertidos, prosélitos de justiça (MELL, 1938, p. 14).

Embora isso não deva ser considerado como uma marca entre os dois grupos pois, mesmo alguns seguidores de Hillel, neste assunto, concordavam com a escola de Shammai (GUTTMAN, 1957, p. 124). Ou seja, ser contra a conversão dos gentios para o judaísmo não garantiria a certeza de que escola se fazia parte. Porém, estar a favor, com bastante segurança, colocaria o grupo entre os seguidores da casa de Hillel. Lucas parece ignorar essas 
escolas e classifica simplesmente como fariseus. Paulo, sendo fariseu, porém, pensa como Pedro: não há necessidade de conversão ao judaísmo para judeu e gentio sentarem-se à mesa, em comunhão.

O que deixa claro, com isso tudo, é que a comunidade de gentios sempre será comunidade de gentios e os judeus continuariam seguindo a lei de Moisés. A comunidade de Mateus, por exemplo, é bastante provável que possua gentios entre judeus (THEISSEN, 2009, p. 247), contudo, a comunhão parece estar bem presente, como vimos. Em outras palavras, para Pedro, Paulo, Barnabé e para os "outros judeus", não há necessidade, ou não se deve converter gentios ao judaísmo, pois Deus, em Jesus, já os aceitou como são. Na teologia de Atos, o derramar do Espírito sobre quem não é judeu comprova isso. Para Paulo, uma revelação de Deus trouxe isso a ele, que foi confirmada por Pedro e por Tiago. Porém, Tiago, ao que parece, convenceu-se sobre sentar-se à mesa com gentios apenas depois da crise em Antioquia.

Sobre esse ponto, há algumas intepretações a se considerar. A primeira delas considera que a crise de Antioquia ocorreu antes da ida de Paulo à Jerusalém, relatada em Gálatas 1. Este relato seria a versão de Paulo sobre o concílio. Então, a crise em Antioquia seria uma consequência do não entendimento sobre as decisões de Jerusalém: os gentios não precisam se circuncidar, mas permanecem impuros? Ou os gentios não precisam se circuncidar e não são mais impuros? Essa é a intepretação de Taylor:

A crise em Antioquia pode, portanto, ser satisfatoriamente explicada como decorrente de duas interpretações bastante diferentes dos decretos de Jerusalém, implicando em duas maneiras diferentes de ver a situação dos convertidos gentios em relação aos crentes judeus. Estrangeiros ou estrangeiros residentes? Sem comunhão ou comunhão sob certas condições? (TAYLOR, 2001, p. 380) - tradução própria.

Uma outra visão, dentre três apresentadas por Dunn, considera que a reunião relatada em Gálatas 1 tenha tratado apenas sobre a circuncisão, e não sobre a comunhão com gentios à mesa:

em Atos 15, o concílio de Jerusalém se pronuncia explicitamente tanto sobre a questão da circuncisão, como se ela não tivesse sido resolvida até então, quanto sobre os requisitos mínimos necessários antes que a comunhão à mesa possa ocorrer (15.20-29); ao passo que o relato de Paulo em Gálatas 2 mostra que a questão da circuncisão já havia sido resolvida antes que a questão da comunhão à mesa se tornasse o assunto de controvérsia (DUNN, 1983, p. 37) - tradução própria.

Resta, para Dunn, um enigma, caso, nessa interpretação, a crise em Antioquia preceda o relato do concílio: por que a circuncisão ainda é um 
problema? Todavia, a circuncisão é um problema ainda bem depois de tudo isso: quando Paulo está escrevendo a carta aos Gálatas. O grupo que tinha como referência, antes de seguirem o mestre Jesus, o rabino Hillel, ainda alimentava a esperança de gerar prosélitos de justiça. Não se satisfaziam com convertidos residentes. Logo, a questão da circuncisão continuaria assombrando os gentios durante um bom tempo.

Portanto, assumindo a percepção de Dunn, há um acordo na visita de Paulo à Jerusalém e tanto ele quanto Barnabé, Pedro e outros judeus, passam a fazer parte de um grupo que defende que a comunhão com os gentios não pode mais ser considerada impura. A única coisa que Tiago transmite a Paulo é que se preocupe com os pobres (G1 2.10). Porém, ele, Barnabé e Pedro sabem que não representam a ala mais forte. Do contrário, evitando criar mais problemas, ou constrangimentos, Pedro, Barnabé e o outros judeus não teriam se afastado dos gentios, com a chegada da comitiva de Tiago.

Tal situação gera uma ira em Paulo, que transforma o banquete da comunhão em uma disputa, na qual, do outro lado, está o grande líder da igreja em Jerusalém, Tiago, o irmão de Jesus. E, sobre o muro, do ponto de vista de Paulo, estão Barnabé, Pedro e outros judeus. Logo, Paulo está em minoria e sem a mesma importância. O problema, contudo, é levado a Jerusalém e, quer histórico ou não, o evento demonstra que Paulo, Barnabé e Pedro estão, de fato, do mesmo lado do debate. Tiago é, por fim, convencido, e transmite a carta que, de uma vez por todas, deixa claro que não há necessidade de conversão dos gentios ao judaísmo, para serem chamados de irmãos (At 15.23), portanto, membros da família.

Paulo demonstra, em Gálatas, fidelidade à carta de Jerusalém. Não concorda nem em chamar seu grupo de convertidos em gentios, mas, segundo ele, mesmo não sendo judeus, são "descendência de Abraão" (Gl 3.29). Como que a conversão ou fidelidade a Deus é capaz de transformar um gentio em membro da família, irmão dos judeus, sem se converter ao judaísmo? Estaria Paulo e Tiago inovando, na teologia judaica? Neste ponto, surge o debate bem presente na comunidade judaica antiga: o verdadeiro israelita.

\section{O coração circuncidado}

Paulo, já avançado nessa reflexão, utiliza a ideia do "verdadeiro israelita", na qual, segundo ele, "A circuncisão é, na verdade, proveitosa, se tu guardares a lei; mas, se tu és transgressor da lei, a tua circuncisão se torna em incircuncisão" (Rm 2.25). Essa ideia aparece em outros escritos do Segundo 
Testamento: "E não presumais, de vós mesmos, dizendo: Temos por pai a Abraão; porque eu vos digo que, mesmo destas pedras, Deus pode suscitar filhos a Abraão" (Mt 3.9). Para a comunidade mateana, o ser descendente de Abraão não deveria ser considerado garantia de nada, pois mesmo as pedras podem virar descendente. Deus tem poder para isso.

Em João, o assunto toma um tom mais sério. Envolve a ideia do bastardo espiritual:

Responderam, e disseram-lhe: Nosso pai é Abraão. Jesus disse-lhes: Se fôsseis filhos de Abraão, faríeis as obras de Abraão. (...) Vós tendes por pai ao diabo, e quereis satisfazer os desejos de vosso pai. Ele foi homicida desde o princípio, e não se firmou na verdade, porque não há verdade nele. Quando ele profere mentira, fala do que lhe é próprio, porque é mentiroso, e pai da mentira. (João 8.39-44).

Aquele que, apesar de ser descendente de Abraão, não segue os caminhos de Abraão. Esse tema é pré-anunciado no prólogo de João (1.11-13): "Veio para o que era seu, e os seus não o receberam. Mas, a todos quantos o receberam, deu-lhes o poder de serem feitos filhos de Deus, aos que creem no seu nome".

Também os rabinos se preocupam bastante com a circuncisão do coração, da boca e do ouvido. Há uma história, inclusive, onde o ser judeu legítimo não garante absolutamente nada, desdenhando, assim, até mesmo, do Sumo Sacerdócio que não segue os mandamentos:

Foi ensinado na Mishna: as pessoas escoltam o Sumo Sacerdote até sua casa. E ele faria um banquete para seus entes queridos. Os Sábios ensinaram em um baraita: Houve um incidente envolvendo um Sumo Sacerdote que saiu do Templo Sagrado e todos o seguiram. Quando eles viram Shemaya e Avtalyon, os chefes do Sinédrio, caminhando, em deferência a eles, eles deixaram o Sumo Sacerdote sozinho e foram atrás de Shemaya e Avtalyon. Eventualmente, Shemaya e Avtalyon vieram se despedir do Sumo Sacerdote, antes de retornar para suas casas. Com inveja da atenção que receberam, ele disse-lhes com raiva: Deixem os descendentes das nações gentílicas virem em paz. Shemaya e Avtalyon descendiam de convertidos, e ele, desdenhosamente, chamou a atenção para esse fato. Disseram-lhe: Que venham em paz os descendentes das nações gentílicas, que praticam os atos de Arão, que amam e buscam a paz; e que não venha em paz um descendente de Aarão que não pratique os atos de Aarão e que fale condescendentemente com os descendentes de convertidos. (Yoma 71b - tradução própria).

Nota-se aqui que os descendentes dos convertidos, ou seja, os que não são sangue puro, podem, inclusive, ter proeminência sobre um sumo sacerdote. A descendência de Abraão e de Arão não é suficiente para garantir o status de devoto, ou fiel a Javé. 
Em um grau mais absurdo ainda - e que responde com que autoridade Paulo chama os gálatas de membros da família de Abraão e com que garantia Tiago pode chamar os gentios de irmãos - está a crença de que um gentio, ao se dedicar ao estudo, pode ser equiparado até mesmo ao sumo sacerdote: "Portanto, você aprendeu que mesmo um gentio que se dedica ao estudo da Torá é considerado um Sumo Sacerdote" (Bava Kamma.38a.11). Ou seja, Paulo e Tiago refletem sobre o que a tradição oral do judaísmo já fazia. São devedores de uma reflexão já presente na tradição.

Quando passam a defender a comunhão com esses, é porque eles entendem que os gentios seguidores de Jesus estão no mesmo nível daquele gentio que se dedica à Torá e se torna como um Sumo Sacerdote. Se a tradição oral é capaz de chegar a essa conclusão, parece fácil, para Paulo e Tiago, concluírem que um gentio da igreja é tão digno da mesa com judeus quanto um sumo sacerdote. Não há conversão ao judaísmo, não há circuncisão. Mas há comunhão entre os filhos de Abraão de origem judaica e os filhos de Abraão de origem gentílica.

\section{Conclusão}

A partir de pesquisas já consolidadas a respeito da nova perspectiva sobre Paulo, procurou-se investigar a respeito da identidade e da comunhão dos convertidos gentios ao seguimento dos apóstolos seguidores de Jesus de Nazaré. Segundo a análise proposta por esse artigo, é preciso compreender esses gentios como, inicialmente, gentios simpatizantes do judaísmo e que eram benquistos entre os judeus. Uma coluna de uma sinagoga encontrada em Afrodisia demonstra claramente isso. Eram tão bem vistos que seus nomes eram escritos na coluna, provavelmente como patrocinadores. O que confirma a possibilidade histórica, que Lucas faz alusão, de que esses gentios poderiam ter ajudado a construir sinagogas.

Após a missão aos gentios, confiada ao apóstolo Paulo, esses simpatizantes, que os rabinos chamam de convertidos residentes, são transformados em “irmãos”, descendentes de Abraão, pela fé em Jesus. Não se tornam judeus e nem convertidos de justiça, para frustração dos chamados judaizantes, que desejam transformar os gentios em judeus de fato.

Essa concepção, porém, não foi fácil de se conseguir. Compreender que eles não necessitam ser circuncidados para fazer parte da comunidade, há bastante apoio na tradição e na história do judaísmo e, por isso, não causou grandes problemas - a não ser para os grupos de judeus oriundos da escola de Hillel, que entendiam que a missão dos judeus era gerar convertidos de 
justiça. A virada para entendê-los como gentios, mas membros da família, ou seja, irmãos, foi a partir da crise em Antioquia. Pois a questão da pureza não estava ainda sendo debatida. Apesar de Paulo, Pedro, Barnabé e alguns outros judeus entenderem diferente. No fim, ao que parece, essa visão foi a preservada e compreendida.

Logo, esses gentios são gentios; permanecem, portanto, com sua cultura e etnicidade preservadas. E, pela fé, são adicionados à descendência de Abraão. A comunidade se vê como uma comunidade escatológica, onde as barreiras culturais são derrubadas, mas as culturas são preservadas. Realizando, assim, a esperança escatológica em torno do Messias.

\section{Referências bibliográficas}

ARBIOL, Carlos Gil. La novedad de Pablo en el Proyecto de Pablo: un debate que no acaba In: FIGUEIREDO, Telmo José Amaral de; CATENASI, Fabrizio Zandonadi. Paulo: contexto e leituras. São Paulo: Paulinas, 2018, p. 105-135.

CROSSAN, John Dominic; REED, Jonathan L. Em busca de Paulo: como o apóstolo de Jesus opôs o Reino de Deus ao Império Romano. São Paulo: Paulinas, 2007.

DUNN, J.D.G. The incident at Antioch (Gal. 2:11-18). Journal for the Study of the New Testament, Sheffield, v. 5, n. 18, p. 3-57, 1983.

GUTTMANN, Alexander. Hillelites and Shammaites - a clarification. Hebrew Union College Annual, New York, v. 28 n. 1, p. 115-126, 1957.

JEREMIAS, Joachim. Jerusalém nos tempos de Jesus: pesquisa de história econômico-social no período neotestamentário. Santo André; São Paulo: Academia Cristã; Paulinas, 2010.

MELL, Glen W. Jewish proselyte baptism and Its relation to Christian baptism. Butler University. Graduate Thesis Collection. n. 201, 1938.

MONASTERIO, Rafael Aguirre; CARMONA, Antonio Rodriguez. Evangelhos Sinóticos e Atos dos Apóstolos. São Paulo: Ave-Maria, 2012.

MURPHY-O'CONNOR, Jerome. Jesus e Paulo: vidas paralelas. São Paulo: Paulinas, 2008.

SANDERS, Ed P. Paulo, a lei e o povo judeu. São Paulo: Paulus, 2009.

TAYLOR, Justin. The Jerusalem decrees (Acts 15.20, 29 and 21.25) and the incident at Antioch (Gal 2.11-14). New Testament Studies, Cambridge, v. 47, n. 3, p. 372-380, 2001.

THEISSEN, Gerd. A religião dos primeiros cristãos: uma teoria do cristianismo primitivo. São Paulo: Paulinas, 2009. 